\title{
DENOTATIVE AND CONNOTATIVE MEANING ANALYSIS IN THE GREATEST SHOWMAN ALBUM
}

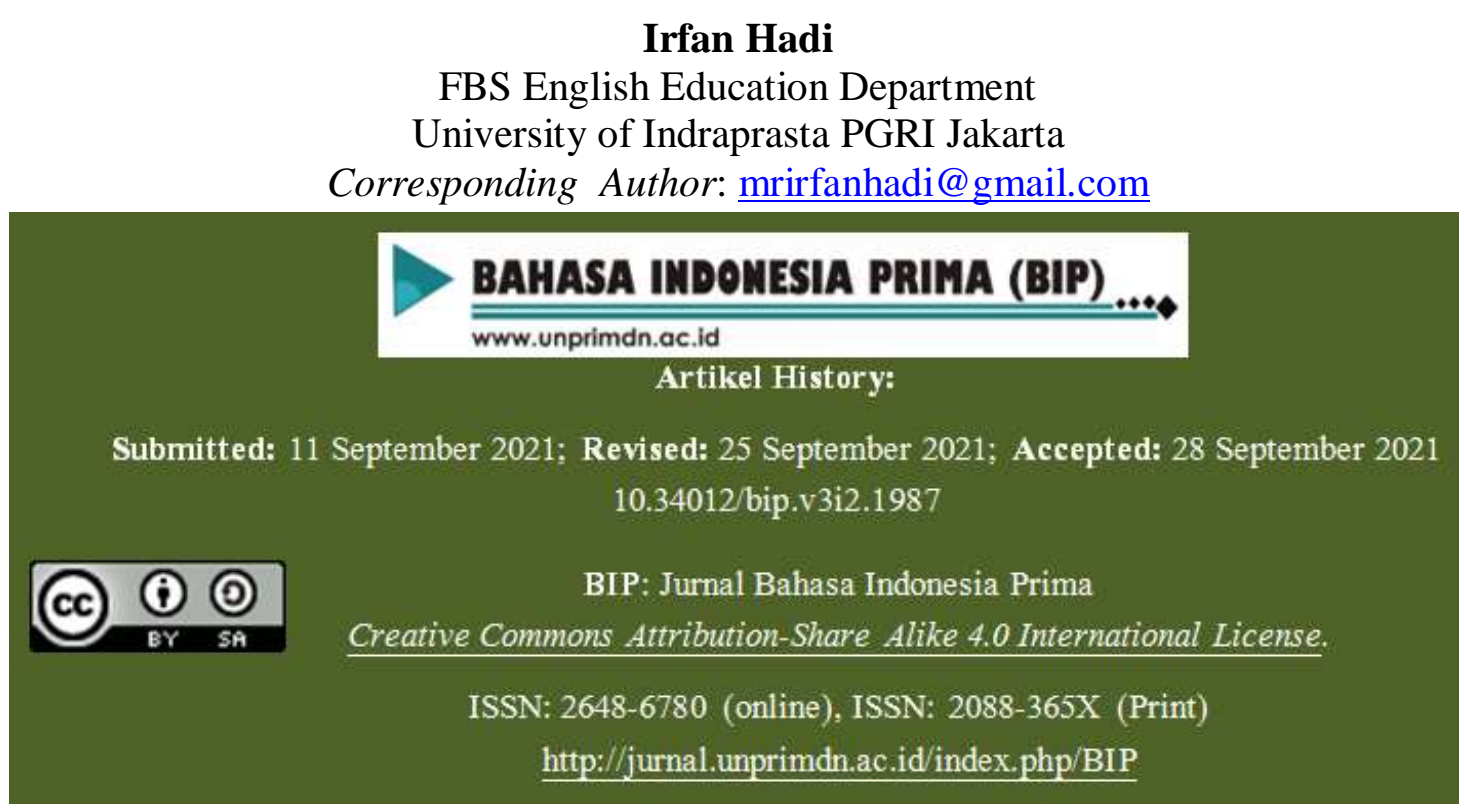

Abstrak-Tujuan dari penelitian ini adalah untuk menganalisis makna denotatif dan makna konotatif yang terkandung dalam lirik lagu pada album The Greatest Showman. Penelitian ini menggunakan analisis kualitatif deskriptif sebagai prosedur untuk melakukan penelitian. Penulis menemukan 27 lirik yang mengandung makna denotatif dan makna konotatif dalam sembilan lagu pada album The Greatest Showman. Hasil penelitian menunjukkan bahwa kata, frasa, atau kalimat dalam lirik lagu dalam album The Greatest Showman mengandung makna denotatif dan konotatif. Makna denotatif menunjukkan makna "kamus". Makna konotatif menunjukkan makna tersirat yang mana menginterpretasikan berdasarkan konteks dalam semua lirik dalam lagu tersebut. Pesan umum dari seluruh lagu The Greatest Showman adalah memberi toleransi dan pantang menyerah untuk mencapai impian kita, menjadi diri kita sendiri, tidak takut untuk menjadi berbeda dan tidak peduli yang orang lain pikirkan atas impian kita

Kata kunci : Denotasi, konotasi, analisis, snowman album

Abstract-The purpose of this research is to analyze of the denotative and connotative meaning that are contained in the song lyrics of the greatest showman album this study uses descriptive qualitative analysis as a procedure for conducting research. The writer finds 10 lyrics that contain the denotative and connotative meaning in the nine songs of the greatest showman album. The results show that the word, phrases or sentences in the lyric song of the greatest showman album included denotative and connotative meaning. The denotative meaning shows the "dictionary" meaning. The connotative meaning shows the implied meaning that is interpreted based on the context of all lyrics in the songs. The general messages from the whole of the songs in the greatest showman are giving tolerance, not giving up on our dream, being ourself, not being afraid to be different, and not caring what others think of our dream.

Key Words : Denotation, connotation, analysis, snow 


\section{A. Introduction}

According to Leech (1981) stated that there are two categories of meanings in semantic. They are denotative meaning and connotative meaning. Denotative is the meaning of a word, which it is primarily, refers to the real word and dictionary definitions. According to Widarso (in Nugroho, 2007:10), denotation refers to the words whose meaning exists in the dictionary. For example, the word "cat" is a carnivorous mammal, domesticated as a rat catcher or pet. On the other hand, According to Barker (2001:4), connotative meaning is the part of the meaning of a word and connotative has an implicit meaning.

For example more, the writer found one lyric song that contains connotative meaning from the songs lyris in The Greatest Showman album. In lyrics "And buried in your bones there's an ache than you can't ignore", there are two words contain connotative meaning which buried and bones. It derived from "bury", according to the dictionary, it implies putting a dead body into the ground. If it fungtion as an adjective, the word "buried" refers to the situation where the dead body placed in the ground. On the other side. The word "bones" that derived from the word "bone" means a hard part that forms a frame in the human or animal body while the word "bones" connotes "life": that is a period between birth and death. So, the real meaning of "burried in your bones" is stored in your life. Therefore, the lyrics implies if there is a continuous pain that stored for a long time in his or her life that he or she was intentionally giving attention to.

One of the literary work that can communicate with others is song. Song is a tune and sounds which consists of melody, lyric, music arrangement, notation. Songs are not only lyric song that the arrangement of words into sentence, but also the representation of the composer's emotion and intention to express personal feeling such as love, struggle, trouble, jealousy, feeling etc. The composer creates the song lyric based on life experience that tells about someone or another like songs from the greatest showman album. Also, lyric song there are some messages sent by the singer or composer to the listener with specific situation or context in song lyrics.

Everytime we listen to music and connect our feelings but there are some people just listen. They do not know the meaning and message from the music; they listen to the lyrics of the song contain many meanings that are not actually and used language that convey variuos of meaning to make the song more beautiful. Furthermore, in understanding what is meant in the lyrics song and knowing the message that exists in the lyrics song, we should learn about meaning in the lyric song. There are many types of meaning in semantic. Such as denotative meaning, connotative meaning, social meaning, affective or emotive meaning, and reflected meaning, collocative meaning and thematic meaning .

The Greatest Showman is the soundtrack album to The GreatestShowman Movie. This album is produced by Justin Paul and Benj Pasek and is released on December 8,2017 by Atlantic Records. The writer uses Song lyrics in The Greatest Showman album because the songs are good to hear and full of meaning. All of the songs lyrics in the album can give us spirit and some life lessons that carry a message with the purpose of motivating the listeners. And also, they have a good moral value 
especially in This is Me and A Million Dream. Based on the interpretation that has been explained above, the writer is interested to analyze the denotative meaning and the connotative meaning in the lyrics of The Greatest Showman album. Based on the background above, the writer identifies the problems are, one, what are the semantic meanings in the songs of The Greatest ?, two, what are the denotative meanings that are shown in the lyric of the greatest showman? three, what are the denotative meanings that are shownin the lyrics of The Greatest Showman album ? four, hat are the denotative meanings that are shown in the lyrics of The Greatest Showman album and five, what are the messages delivered in the lyrics of The Greatest Showman?

Based on the scope of the research, formulates research question as follows :

1. What are denotative and connotative meanings that are shown in the lyrics of The Greatest Showman album?

2. What are the messages delivered in the lyrics of The Greatest Showman album?

The aims of this study are able to help in gaining the objective of the research. The aims of this research are:

1. To find out the denotative meaning and the connotative meaning that are shown in the lyrics of The Greatest Showman album.

2. To know and understand the message delivered in the lyrics of The Greatest Showman album.

\section{B. Metode Penelitian}

The research uses a descriptive qualitative approach. The descriptive qualitative research approach is chosen because the data analyzes in the form of descriptive texts, not in the form of numbers, symbols or coefficient about relationship between phenomena and absolutely it was made the data information more objective and easier to understand.

Denzin and Lincoln (2011:34) said that qualitative approach is a process of research and understanding of researchers and subjects under study. It means that research which is conducted is a process and an understanding of research subject under a study by the researcher.

The approach used by the writer in conducting this research is qualitative research. According to Creswell (2013:62), "Qualitative research is an inquiry approach useful for exploring and understanding a central phenomenon. To learn about this phenomenon, the inquirer asks participants broad, general questions, collect the detailed views of informationfor description and themes. From this data, the researcher interprets the meaning of the information, drawing on personal reflections and past research. The final structure of the final report is flexible, and it displays the researcher's biases and thoughts."

It means that qualitative research is a research for surveying and understanding a primary occurrence. There are several research technique used in this research, as follows: Collecting the data. This data stage is by listening to the song "The Greatest Showman". The writer looks for the connotative meaning and denotative meaning that appears in the lyrics songs.Classifying the data, In this stage, research data about the analysis of the connotative meaning and denotative meaning that is contained in the song lyrics in

"The Greatest Showman". Therefore, the writer make classification based on the 
songs that there are nine songs in The Greatest Showman. Analyzing the data, In analyzing the data, the writer analyzes the data to describe and to elaborately describe the words or phrases in the lyrics song that contain the connotative meaning and denotative meaning. Afterwards, the analyzed data is carried comprehensively for getting data validity, and it is explained into specific explanations. After that, the data will be described in the form of a particular and table. Drawing a conclusion, In this stage, the writer draws a conclusion based on analyzing data results that have been obtained. The conclusion is summarized thoroughly into description about the analysis of connotative meaning and denotative meaning that is contained in the song lyrics especially in "The Greatest Showman" album. And also, the messages that are delivered in "The Greatest Showman" album.

\section{Result and Discussion}

In this part, the writer shows the table which exists the denotative and connotative meanings in the lyrics of The Greatest Showman album. In the table, the writer uses a code in order to make the reader read the analysis data easily. The symbol of " $D$ " represents the number of data, The symbol of " $\mathrm{S}$ " represents the number of songs, and the symbol of " $L$ " represents the line of the lyrics song.

Table 4.1 Data Finding

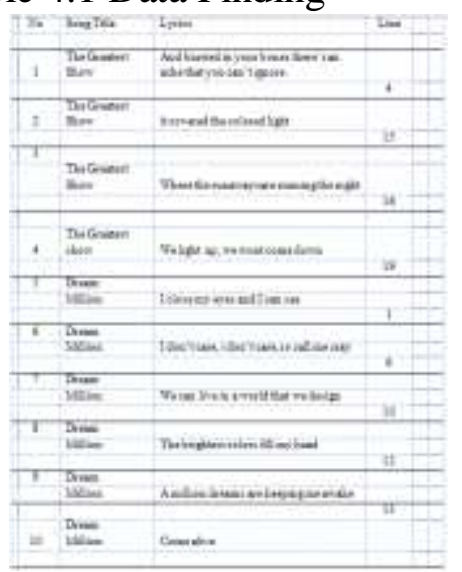

In this part, the writer analyzes the denotative and connotative meanings in the lyrics song of the greatest showman. The writer takes nine songs in the greatest showman album as the data. The data is analyzed descriptively based on the theory of denotative and connotative meaning by Geoffrey Leech (1981) and others theories to support this research. To answer the denotative meaning uses Oxford Advanced Learners Dictionary. To finding the connotative meaning interprets based on context from all lyrics in the song and theme of the movie.

\section{a. The Greatest Show}

"And buried in your bones there's an ache that you can't ignore".

In the dictionary meaning, The word "buried" here is past participle as an adjective word. It is derived from the word "bury". The word "bury" means putting a dead body into the ground. If it functions as an adjective, the word "buried" refers to the situation where the dead body is placed in the ground. Meanwhile, the word "bone" means a hard part that forms a frame in the human or animal body.

The lyric "And buried in your bones" here is not true meaning but it includes connotative meaning. To found the connotative meaning, the writer interprets based on the context of all lyrics in the song. The word "bones" connotes life that is aperiod between birth and death. Therefore, the real meaning of the lyric "And buried in your bones" is stored in your life.

The lyric above delivers the message that if there is a continuous pain that stored for a long time in our lives, we cannot ignore it even though many things can hurt our feelings such as disappointment, rejection, desperation, and so on. So, don't 
make the pain prevent to have happiness and a better life.

\section{b. "It covered the colored lights"}

In the dictionary meaning, the word "colored" here is past participle as an adjective word. It is derived from the word "color". It means the appearance that things have that results from the way in which they reflect light. If it functions as an adjective, the word "colored" means having a particulary color or different colors. The word "lights" that derived from the word "light" means; (1) the energy from the sun, a lamp, etc. that makes it possible to see things, (2) a thing that produces light, especially an electric light.

The lyrics "It covered the colored light" has connotative meaning. To found the connotative meaning, the writer interprets based on the context in all lyrics in the song. This lyric connects with the previous song lyrics, "tell me do you wanna go?" which asks a person to tell them if you want to go. The word "Go" refers to moving and leaving the previous life that was only spent hidingand shame. Therefore, the phrase "the colored light" connotes hope and imaginations. So the real meaning of "where it's all the colored light" is someone who wants to go to a place full of imaginations for the future that has never been done before or never been dreamed about before and hopes to change life to be better.

The lyrics deliver a message that everyone has the same right to have hope for a better future. Nothing is impossible when we strongly decided to achieve every dream and turning hope into reality.

c."Where the runaways are running the night".

In the dictionary meaning, the word "runaways" is derived from the word "runaway". It means someone who has left without telling anyone or without permission. In the other side, runaways also mean someone who has escaped or run away from somewhere.

The word "runaways" has connotative meaning. To found the connotative meaning, the writer interprets based on the context of all lyrics in the song. The word "runaway" means the joining and running the night of his circus performances. This song tells about excitement when someone comes to the circus. The word "Runaway" here is an expression used when someone doesn't have a solid plan for their future or is planning something ludicrous. So the circus itself is comprised of these very people. Runawayinterprets as a breakout from the hideout and they want to show that everyone has talent, a breakout from the shadows and perform ridiculously.

The lyric above delivers a message to go to somewhere you wanna go where a place you found courage that you didn't have before in you. It changes your lives and always remembers that everyone has talent in something.

d. "We light up, we won't come down"

In the dictionary meaning, the phrase "light up" means to become or to make something bright with light or color. Meanwhile, the phrase "come down" here is a phrasal verb. It means to break and fall to the ground.

The lyric "We light up, we won't come down" is not the true meaning but it includes the connotative meaning. To found the connotative meaning, the writer interprets based on the context of all lyrics in the song. The phrase "come down" here connotes to give up or to stop trying to do something. So the real meaning of the lyric "we light up, we won't come down" is some people that just start but there are 
many obstacles that they got and tell that they never give up to get the amazing result/huge thing.

The lyric above delivers the message to never give up and keep shining. No matter how bad it gets, if you want to be the greatest or make the biggest impact never, ever, give up

\section{A Million Dream}

\section{e. "I close my eyes and I can see"}

In the dictionary meaning, the word "close" means close which causes something to change from being open to not being open. Meanwhile, the word "eyes" means one of the two organs on the face that are used for seeing. The literal meaning of "close my eyes" means when someone closes their eyes, the eyelids move downwards, so that they cannot see anything and it is just dark.

The lyrics above "I Close my eyes and i can see" is not the true meaning. This lyric describes that someone closes his eyes and yet being able to see. In the other hand, a person literally cannot see anything in a closed eye which we can feel is just dark. The lyric above has connotative meaning. To found connotative meaning, the writer interprets based on the context of all lyrics in the song. The sentence "I close my eyes" connotes that someone is able to display his ability to ignore criticism. Meanwhile, the sentence "I can see" connotes someone can see many things such as can imagine to a whole new world of possibilities and dreams for his future.

The lyric above delivers a message to disregarded the negativity around you. Don't let others be too influential in your life, especially the ones who are critical of you and what you are accomplishing. It may take some time and effort to rid yourself of critical and unsupportive people, but replacing those with an encouraging support system will be invaluable such as can imagine dreams for the future.

f. "I don't care, I don't care, so call me crazy".

In the dictionary meaning, the word "crazy" means having or showing severe mental illness, especially as manifested in a wild or aggressive way and uncontrolled. It also means being unable to think in a clear or sensible way.

The word "crazy" here is not the true meaning. The word here doesn't mean having mental illness but it included connotative meaning. To found the connotative meaning, the writer interprets based on the context of all lyrics in the song. Therefore, the sentence "I don't care" means someone that not caring what others think of the dream. Meanwhile, the word "crazy" connotes having a dream so big or vision that others think it imposibble to reach it.

The lyric above delivers the message to focus on your dream and forget everyone else. It is obvious that the lyric delivers a message to not caring what others think of your dream, you have to keep focus and try to reach your dream because hard work neverlies a dream. And also, you have to believe in your vision that your dreams will come true.

g. We can live in a world that we design

According to the dictionary, the word "live" means to be alive or have life, especially at a particular time and particular place. The word "world" means Meanwhile, the word "design" have several meaning. It means; (1) the general arrangement of the different parts of something that is made, such as a building, book, machine, etc. (2) the art or process 
of deciding how something will look, work, etc.

The lyric above "We can live in the world that we design" is not the real meaning. Humans literally can't design the world because just only God can design the world. Therefore, the word "design" has the connotative meaning. To found the connotative meaning, the writer interprets based on the context of all lyrics in the song. The word "design" connotes to regulate the way of life in its own way. The lyric "We can live in the world that we design" implies someone can run their life with regulate the way of life in its own way.

The lyric deliver a message that we can make the way of life in its own way because your life doesn't decide with others. We can regulate what is the best for better life.

\section{h. The brightest colors fill my head}

According to the dictionary, the word "brightest" is superlative adjective. It derived from the word "bright" means full of light, shining strongly and easy to see. Meanwhile the word "colors" means having a particulary color or different colors. Hence, the literal meaning of "the brightest colors" means a bright colour that full of light, noticeable, and not dark. The last word "head" means the part of the body on top of the neck containing the eyes, nose, mouth and brain.

The lyrics above "The brightest color fill my head" here is not the true meaning. The human head literally is an anatomical unit consisting of a skull, hyoid bone, and neck bone that cannot be filled with bright color. Therefore, the lyric "The brightest color" here has connotative meaning. To found the connotative meaning, the writer interprets based on the context of all lyrics in the song. The phrase "The brightest color" connotes are likened to positive thoughts that are in head. So the lyric "The brightest color fill my head" implies hope or imagination that always in thinking.

The lyrics delivers a messages implicitly to never lose hope. We must cultivate hope in order to believe that we are capable and can reach our dreams.

i. A million dreams are keeping me awake

In the dictionary meaning, A million is a cardinal number that a symbol for the number 1.000.000. The word "dream" means an imaginary series of events that you experience in your mind while you are asleep. Meanwhile the word "keep" means to continue doing something or to do something repeatedly and the word "awake" means not sleeping. The literal meaning of " a milion dream are keeping me awake" means prevent someone from sleeping by a million dream that she thinking of it.

The lyric "A million dream are keeping me awake" is not the true meaning. Literally when somenone dream cannot dream up to a million and cannot it still awake. Therefore, the frase "a miilion dream" has connotative meaning. To found the connotative meaning, the writer interprets based on the context of all lyrics in the song. The frase "a million dream" connotes having many dream and hope that are being persued by someone. So the real meaning of lyric "A million dream are keeping me awake" implies having many dream that make keep spirit find ways reach the dream or goals.

The lyric above delivers a message implicitly that dream is the energy that makes we keep spirit find ways reach our goals and how to do it.

\section{j. Come Alive}

"Brighten up your darkest day" 
In the dictionary meaning, the word "darkest" is superlative adjective. It is derived from the word "dark". The word "dark" means having very little light, not light in color, a color that closer to black than white. Meanwhile, the word "day" means a period of 24 hours, especially the time between when it becomes light in the morning and when it becomes dark in the night.

The song lyrics above "Brighten in your darkest day" is not the true meaning. The frase "darkest day" here doesn't mean your day is dark there isn't light but it includes connotative meaning. To found the connotative meaning, the writer interprets based on the context of all lyrics in the song. The frase "darkest day" connotes a sad day or a day that have diffult thing through it. So the lyrics above "brighten in your darkest day" implies make a sad day become a happy day.

The lyric delivers the message to change your sad day become happy day. And also, the lyric reminds us that life is like a long journey that must be passed; only there are two options that we can choose. The right path or the wrong path, the right path will lead us to a life of the delight and the wrong path will take us to a life of the sadness.

\section{Conclusion}

We found 10 lyrics that contain the denotative and connotative meaning in the two songs of The Greatest Showman album. It can be concluded that the word, phrases or sentences in the lyric song of the greatest showman album includes denotative and connotative meaning. The denotative and connotative has the different meaning. The denotative meaning shows the "dictionary" meaning, other words the lexical meaning of the word. The connotative meaning shows the implied meaning that is interpreted based on the context of all lyrics in the songs. The results show that the denotative and connotative meaning have an important role to findings the meaning of lyric song and knowing the message of lyric song in the greatest showman album. The general messages from the whole of the songs in The Greatest Showman are giving tolerance, not giving up on our dream, being ourself, not being afraid to be different, not caring what others think of our dream.

\section{Bibliography}

Ati, A. P., Sandiar, L., Widiyarto, S., \& Harie, S. 2021.Ajaran Moral Dan Karakter Dalam

Buku Cerita Nusantara Sebagai Bahan Ajar Siswa Sd. Basastra, 10(1), 46-54.

Barker, Chris. 2001. Lexical Semantic. USA: San Diego Press. Chaer, A. 1994. LinguistikUmum. Jakarta: PT. Rineka Cipta.

Cresswell, John. (2003. Research design: qualitative, quantitative, and mixed method approaches. California: SAGE.

Cruise, Alan. D. 2000. Meaning in

Language. New York: Oxford University. Kreidler, Charles W. 1998. Introducing English Semantics. London: Routledge.

Febriyanti, R. H., Hadi, I., \& Saputri, N.

L. (2018, September). Penerapan penggunaaneclectic method dalam pengajaran bahasa Inggris pada guru SDIT dan SMPIT. In Seminar Nasional dan Diskusi Panel Multidisiplin Hasil Penelitian dan 
Pengabdian Kepada Masyarakat 2018 (Vol. 1, No. 1).

Hadi, I., \& Saputri, N. L. (2020).

Representation of Social Criticism in the Documentary

Film Netflix: Miss Americana. International Journal of Education, Information Technology, and Others, 3(3), 567-573.

Kridalaksana, H. 2008. Kamus Linguistik (4th ed). Jakarta: PT Gramedia Pustaka Utama.

Leech, Geoffrey . 1981. Semantics: The Study of Meaning. London: Penguin Press.

Pateda, Mansoer. 2001. Semantik Leksikal. Jakarta: Rineka Cipta.

Saputri, N. L., \& Hadi, I. I. (2021). An Analysis Of Idiom Expressions In Novel "Mary Poppins" By P1 Travers. Jurnal Lentera Pendidikan Pusat Penelitian Lppm Um Metro, 6(1), 14-30.

Sugiyono. 2014. Metode Penelitian Pendidikan Pendekatan Kuantitatif, Kualitatif, dan $R \& D$. Bandung: Alfabeta.

Widarso, W. 1989. Bahasa Inggris: Dialek, Ragam, Jargon, Slang, Blends, Clipped Words. Jogakarta: Kanisius.

Widiyarto, S., \& Sartono, L. N. (2020). Analisis nilai pendidikan karakter dan moral film koala kumal. Pena Kreatif: Jurnal Pendidikan, 9(2), 50-53.
Yule, George. 1985. The Study of Language: an Introduction. New York: Cambridge University Press.

Hadi, I. (2021). An Error Analysis of Active and Passive Voice Towards English Text of University Students in South Jakarta. Jurnal Ilmiah Wahana Pendidikan, 7(2), 9-16. 